\title{
The ammonoids from the Three Forks Shale (Late Devonian) of Montana
}

\author{
Dieter Korn ${ }^{*, 1}$ \& Alan Titus ${ }^{* *, 2}$ \\ ${ }^{1}$ Museum für Naturkunde der Humboldt-Universität zu Berlin, Invalidenstraße 43, D-10115 Berlin, Germany \\ 2 Grand Staircase-Escalante National Monument, 190 East Center Street, Kanab, UT 84741, U.S.A.
}

Received 19 December 2005, accepted 10 March, 2006

Published online 17 July 2006

With 7 figures

Key words: Ammonoidea, biostratigraphy, Three Forks Shale, Late Devonian, Montana.

\begin{abstract}
The ammonoid fauna from the Late Devonian Three Forks Shale of Montana is revised. Six taxa were recognised, which belong to the genera Tornoceras, Pernoceras, Raymondiceras, Platyclymenia, Pleuroclymenia, and Carinoclymenia. The ammonoid assemblage suggests a stratigraphic position within the middle Famennian, most probably the Platyclymenia annulata Zone. The ammonoids display extreme septal crowding in intermediate as well as adult growth stages, which can be regarded as evidence for instable palaeoecological conditions during lifetime of the animals.
\end{abstract}

Schlïsselwörter: Ammonoidea, Biostratigraphie, Three Forks Shale, Oberdevon, Montana.

\section{Zusammenfassung}

Die Ammonoideenfauna aus dem oberdevonischen Three Forks Shale von Montana wird revidiert. Sechs Taxa werden unterschieden; sie gehören zu den Gattungen Tornoceras, Pernoceras, Raymondiceras, Platyclymenia, Pleuroclymenia und Carinoclymenia. Die Ammonoideen-Vergesellschaftung spricht für eine stratigraphische Position im mittleren Famennium, wahrscheinlich in der Platyclymenia annulata Zone. Die Ammonoideen zeigen auffällige Drängung der Septen in intermediären und adulten Wachstumsstadien, die als Hinweis auf instabile Lebensbedingungen für die Tiere gewertet werden kann.

\section{Introduction}

The ammonoid fauna from the Three Forks Shale of Madison County, Montana, was for a rather long period the only rather rich Famennian assemblage from the New World. It was discovered by Percy E. Raymond, who in three articles (Raymond 1907, 1909, 1912) provided descriptions of his five new species Tornoceras crebriseptum, Tornoceras douglassi, Prolobites simplex, Platyclymenia americana, and Platyclymenia polypleura. $\mathrm{He}$ already attributed the rocks with this fauna to the 'latest Devonian'.

The material, stored in the Carnegie Museum, Pittsburgh was then studied by Schindewolf in 1933. In the following year, he published a discussion of the assemblage and reached the conclusion that the fauna has to be attributed in the 'Prolobites-Platyclymenia-Stufe' (Schindewolf 1934). His revision included the confirmation of the four species erected by Raymond and the establishment of the new genus Raymondiceras for 'Prolobites simplex', but he was not able to

\footnotetext{
* Corresponding author: e-mail: dieter.korn@museum.hu-berlin.de

** e-mail: AlanTitus@blm.gov
} 
assign this remarkably simple-sutured ammonoid to a specific ammonoid group. A relationship with the superficially similar Middle Devonian genus Subanarcestes Schindewolf, 1933 was taken into consideration, but also the possibility that Raymondiceras derived from cheiloceratids, in possessing a secondarily simplified morphology.

Miller (1938) later revised and re-figured the fauna and discussed its stratigraphy once again. He was also puzzled by the composition of the fauna and not sure about the age of the assemblage, but stated that it "... is almost certainly younger than that of the Canadaway with Manticoceras" (Miller 1938, p. 9).

The Three Forks fauna lost its exclusivity, caused mainly by the peculiarly simple morphology of Raymondiceras, with the description of the speciesrich Famennian ammonoid assemblages from the South Urals by Bogoslovsky (1960, 1971). Bogoslovsky found another species that he treated as Raymondiceras, R. aktubense (now attributed to Roinghites Korn, 2002) from middle Famennian rocks of Kazakhstan. Petersen (1975) added a third species to the genus, $R$. inceptum, from the Platyclymenia horizon of Western Australia.

House (1962), who figured some of the species described earlier, contributed the additional new species Rectoclymenia haynesi from the Three Forks Shale. In a subsequent article (House 1965), he described Tornoceras crebriseptum in detail.

A rich collection of new material from several exposures at Three Forks (Fig. 1) was assembled by A.T. between 1993 and 1995 and serves as the basis for the revision of the ammonoid fauna. It was surprising that, despite of the repeated reports on the ammonoid assemblage from the Three Forks, new data could be gained that allow an update of the knowledge of this occurrence.

\section{Stratigraphy}

The Three Forks Formation was named by Peale (1893). Although he did not designate a type section, the Milligan Canyon area west of the town of Three Forks has been used as such by default. The formation as originally defined included all of the clastic and mixed carbonate clastic less resistant strata between the underlying Jefferson Dolomite (Devonian) and the overlying Lodgepole Limestone (Mississippian). Later, the Three Forks Formation was divided by Sandberg (1965) in the type area into, in ascending order, the Logan Gulch, Trident, and Sappington Members. Most of the unit has a Late
Devonian (Fammenian) age, however the upper few meters of the Sappington Member belong unequivocally to the Early Carboniferous (Tournaisian).

The ammonoids described herein all come from the Trident Member, which consists almost entirely of greenish or reddish weathering grey shale with concretions of limonite and siderite. Fossils, including cephalopods are locally abundant. The type section of the Trident Member is only a few kilometers northeast of Milligan Canyon section discussed herein, so correlation of the ammonoid bearing unit there, as well as that of the other locality, is straightforward. Although the lithology of the Trident Member is fairly monotonous, there is a distinct succession of fossils. Small limonitic internal molds of ammonoids, especially tornoceratids, seem more common in the lower part of the studied section. Larger ammonoids and nautiloids, along with a sparse benthic fauna of bivalves and gastropods, become more common upsection, but then disappear, being replaced by a rich brachiopodbryozoan dominated benthic fauna.

Although the Three Forks Shale is mapped widely in southwestern Montana, good exposures of the ammonoid bearing Trident Shale Member are actually quite uncommon.

The junior author examined two localities during a limited survey of Three Forks Shale outcrops done in the summers of 1990 and 1995, both of which had been reported previously by Sandberg (1965). The first locality is within Milligan Canyon (Fig. 1), just over 8 kilometers west of the town of Three Forks. The Milligan Canyon drainage is classically viewed as the type section for the Three Forks Shale, however, good outcrops of the Trident Member with ammonoid fossils were found to be limited to a rather small area. Exposures are best in the east-center of Sect. 36, T 2 N, R 1 W (Montana Principal Meridian), along a small north trending drainage. The lower contact of the Trident Member with the underlying Logan Gulch Member is not exposed, and the lowest exposed bedrock in the immediate succession is a prominent andesite sill that is pervasive in the area. Just above the hornfels caused by the sill are excellent, generally north-dipping outcrops of the upper portion of the Trident Member and the overlying Sappington-Lodgepole sequence. A measured section was recorded and all Milligan Canyon specimens came from this locality (Fig. 1). Ammonoids generally decrease in abundance upsection, coincident with the appearance of orange 


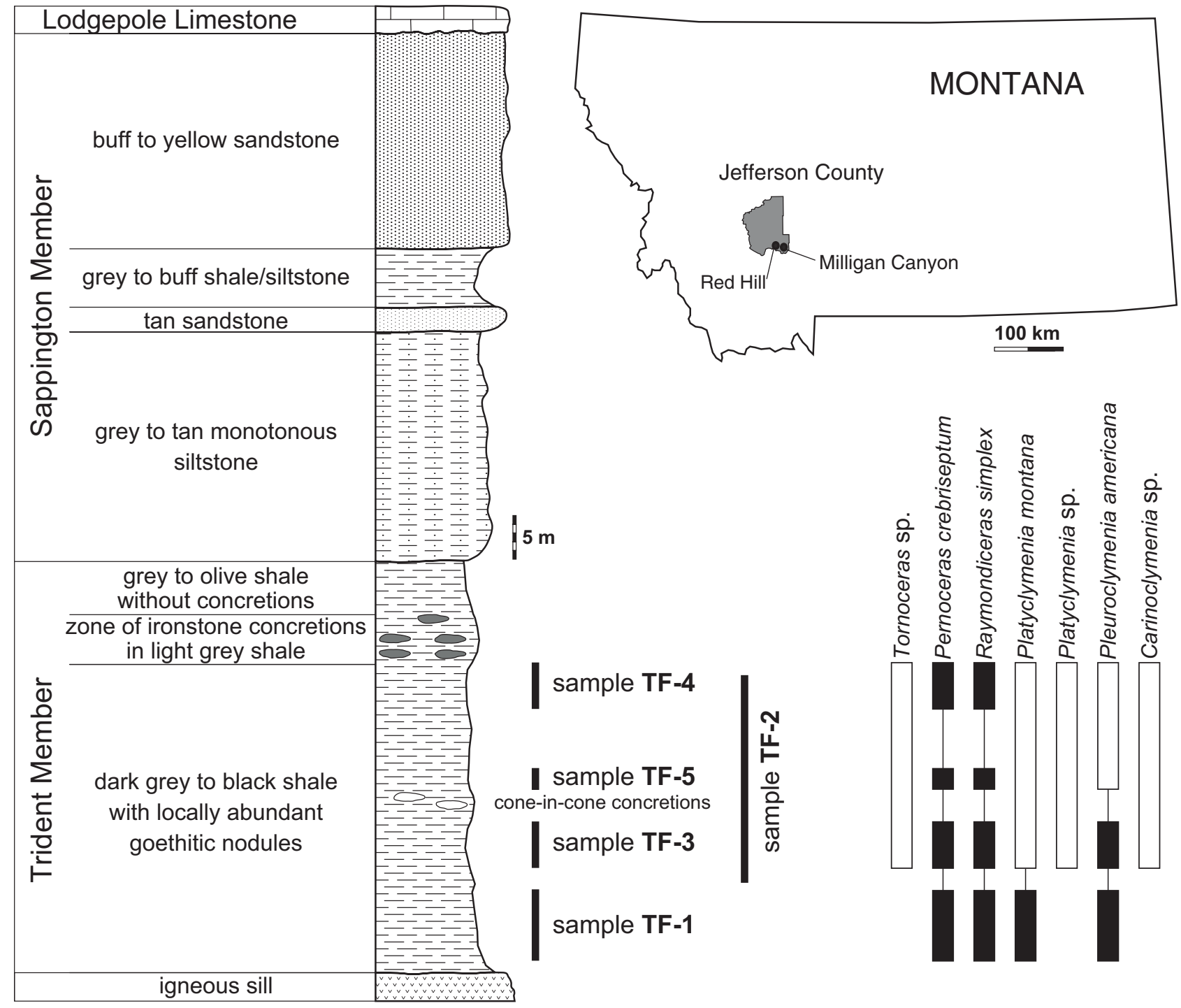

Fig. 1. Geographic position of the Three Forks localities, columnar section of the Milligan Canyon section, and stratigraphic range of the ammonoid species within the section.

and yellow weathering sideritic carbonate concretions and a much more abundant and diverse benthic fauna.

The second locality on Red Hill, is located about 22 kilometers west and slightly north of the Milligan Canyon section in the center of Sect. 22, T.2.N, R.3.W (Fig. 1). Exposures of the middle and upper portions of the Trident Member are better at Red Hill, but the remainder of the section is not as well exposed, and the base of the Trident was not seen. In overall aspect the section is similar to that of the Milligan Canyon area, but is somewhat thicker. Ammonoids were especially common at this locality, indicating the collecting had probably not occurred there for many years. Unfortunately, the nature of the outcrop made collecting with a high degree of stratigraphic control exceedingly difficult.

\section{Palaeontological descriptions}

\section{Material}

240 specimens are available for study. The majority of these specimens, however, are fragments, and distinct specific interpretation is not always possible. Except for a few individuals, the entire material is preserved as limonite (previously markasite) steinkern specimens that only rarely bear remains of the shell.

Suborder Tornoceratina Wedekind, 1918

Family Tornoceratidae von Arthaber, 1911

\section{Tornoceras Hyatt, 1884}

\section{Tornoceras sp.}

Figs 2A, 3A

Material. One specimen (MB.C.9126) from Red Hill.

Description. Specimen MB.C.9126 has $17.5 \mathrm{~mm}$ conch diameter and differs in several 


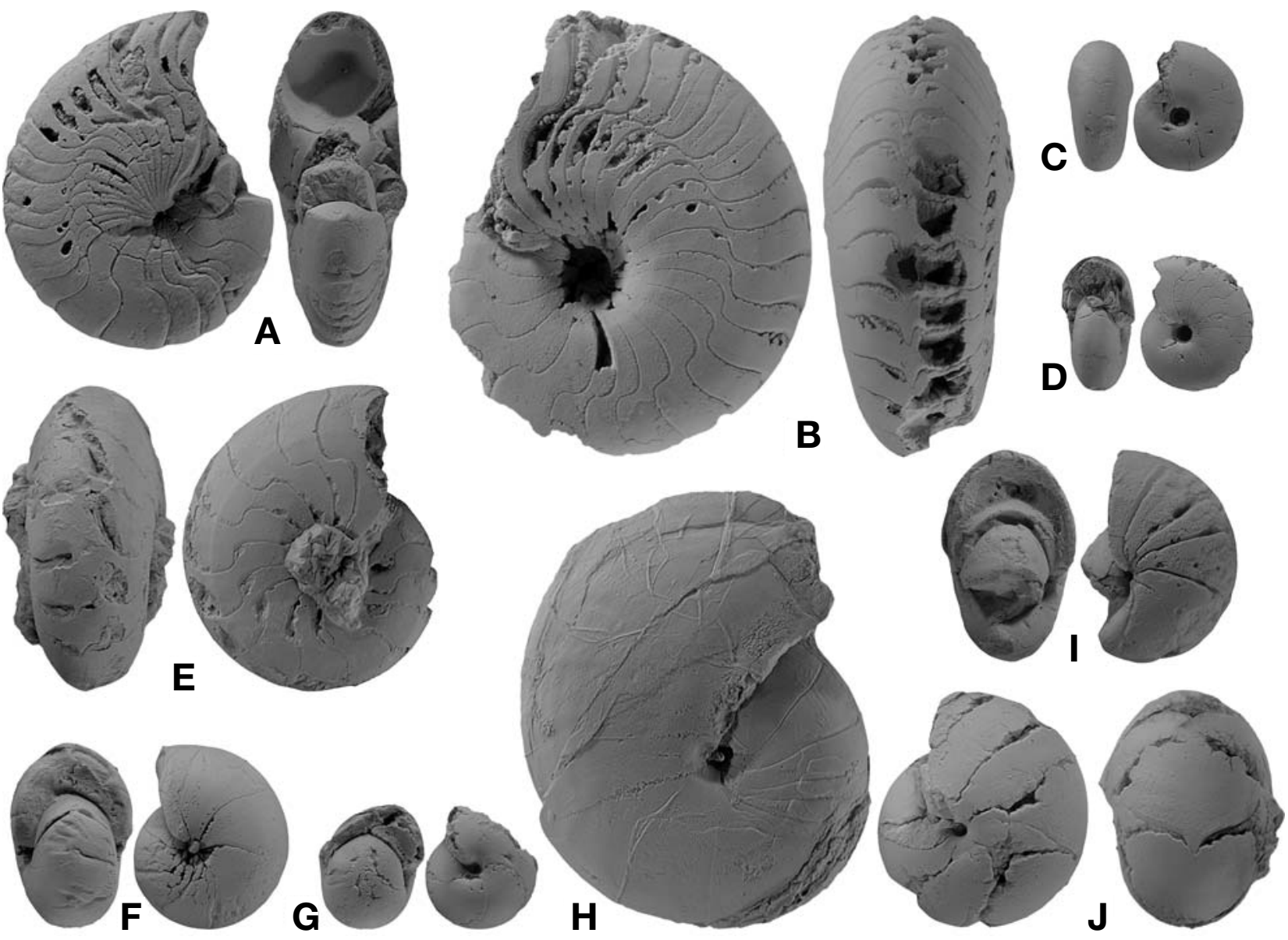

Fig. 2. Tornoceratin ammonoids from the Three Forks Shale of Montana, coll. Titus, all $\times 2.5$. A - Tornoceras sp., specimen MB.C.9126 from Red Hill, lateral and dorsal views; B - Pernoceras crebriseptum (Raymond, 1909), specimen MB.C.9140.1 from Milligan Canyon (sample TF-2), lateral and ventral views; C - Pernoceras crebriseptum (Raymond, 1909), specimen MB.C.9145.1 from Milligan Canyon (sample TF-3), ventral and lateral views; D - Pernoceras crebriseptum (Raymond, 1909), specimen MB.C.9145.2 from Milligan Canyon (sample TF-3), dorsal and lateral views; E - Pernoceras crebriseptum (Raymond, 1909), specimen MB.C.9140.2 from Milligan Canyon (sample TF-2), ventral and lateral views; F - Raymondiceras simplex (Raymond, 1909), specimen MB.C.9134.2 from Red Hill, dorsal and lateral views; G - Raymondiceras simplex (Raymond, 1909), specimen MB.C.9146.1 from Milligan Canyon (sample TF-3), dorsal and lateral views; H - Raymondiceras simplex (Raymond, 1909), specimen MB.C.9134.1 from Red Hill, lateral view; I - Raymondiceras simplex (Raymond, 1909), specimen MB.C.9134.3 from Red Hill, dorsal and lateral views; J - Raymondiceras simplex (Raymond, 1909), specimen MB.C.9149.1 from Milligan Canyon (sample TF-4), lateral and ventral views.

characters from the co-occurring Pernoceras crebriseptum described below. The umbilicus is completely closed in this specimen, and there is not a well-developed umbilical margin. The specimen is fully septate, with strikingly variable septal distances on the last volution. Septal distance at the beginning of the last whorl is about $18-25^{\circ}$, but then there are two septa spaced 10 and $7^{\circ}$, respectively. The next distances are then $14^{\circ}, 17^{\circ}, 29^{\circ}$, and $19^{\circ}$. This irregularity, but with lower distances, is maintained toward the end of the phragmocone. The suture line is typical for Tornoceras with a shallow, asymmetric adventive lobe and a small external lobe (Fig. 3A).

Discussion. It is surprising that a representative of the genus Tornoceras is still present in such a high horizon in the middle Famennian. The morphology of the specimen, however, does not allow any other attribution. It does not possess any traces of ventrolateral grooves, as characteristic for Phoenixites Becker, 1993 that would place it into the group of tornoceratids that are more frequent in Fammenian rocks. The shallow adventive lobe is also a criterion that places the specimen in the genus Tornoceras, rather than Phoenixites.

\section{Pernoceras Schindewolf, 1922}

\section{Pernoceras crebriseptum (Raymond, 1909)}

Figs 2B-E, 3B-D

1909 Tornoceras crebriseptum Raymond: 153, pl. 8: figs 5-7 (only).

1909 Tornoceras douglassi Raymond: 155, pl. 8: figs 9-14.

1934 Tornoceras crebriseptum. - Schindewolf: 331, textfig. 1. 

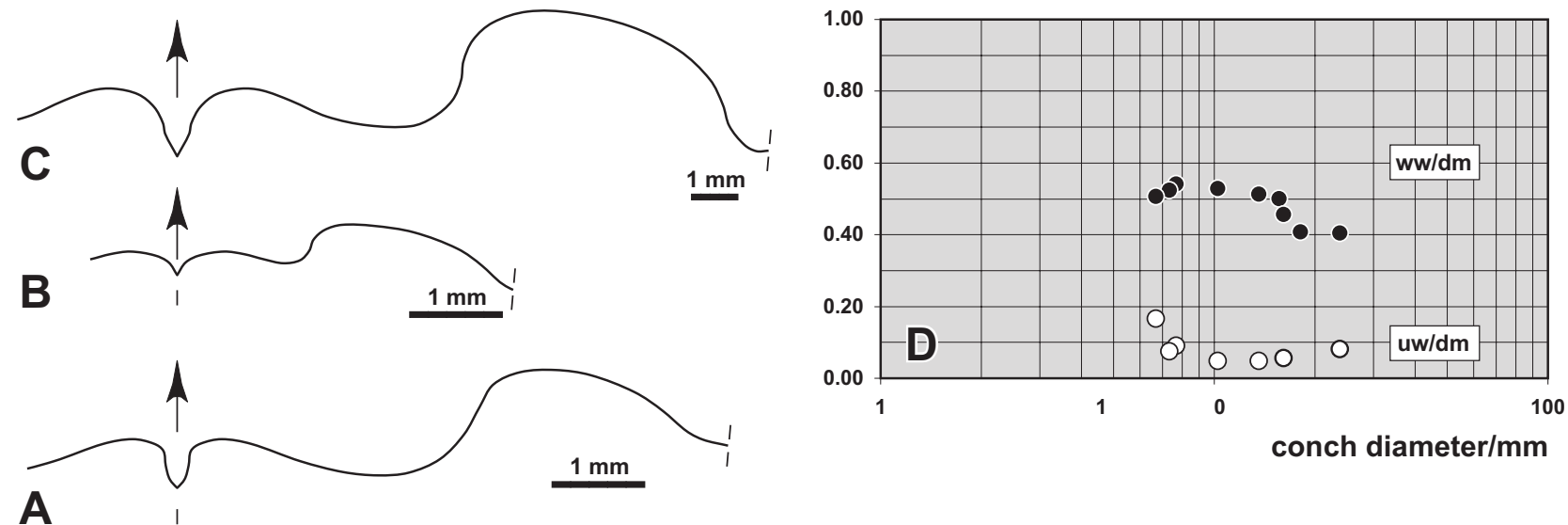

Fig. 3. Suture lines (A-C) and bivariate plots (D) of tornoceratin ammonoids from the Three Forks Shale. A - Tornoceras sp., specimen MB.C.9126 from Red Hill, at $\mathrm{dm}=15.4 \mathrm{~mm}$, ww $=6.1 \mathrm{~mm}$, wh $8.7 \mathrm{~mm}, \times 10$; B - Pernoceras crebriseptum (Raymond, 1909), specimen MB.C.9145.1 from from Milligan Canyon (sample TF-3), at $\mathrm{dm}=5.8 \mathrm{~mm}$, ww $=3.3 \mathrm{~mm}, \times 10$; C-Pernoceras crebriseptum (Raymond, 1909), specimen MB.C.9140.1 from from Milligan Canyon (sample TF-2), at $\mathrm{dm}=20.9 \mathrm{~mm}, \mathrm{ww}=9.3 \mathrm{~mm}$, wh $=11.2 \mathrm{~mm}, \times 15 ; \mathbf{D}-$ Ontogenetic development of the whorl width index $(\mathrm{ww} / \mathrm{dm}) \mathrm{and}$ umbilical width index (uw/dm) in Pernoceras crebriseptum (Raymond, 1909).

1938 Tornoceras (Tornoceras) crebriseptum. - Miller: 149, pl. 38: figs 7-16.

1965 Tornoceras (Tornoceras) crebriseptum. - House: 115, pl. 11: figs $117-119$.

Holoty pe. Specimen 464 (Carnegie Museum, Pittsburgh).

Type locality and horizon. Three Forks (Montana); probably basal portion (red shale) of the Trident Member of the Three Forks Shale (probably Platyclymenia annulata Zone, middle Famennian).

Material. 38 specimens, which range from 5 to about $35 \mathrm{~mm}$ phragmocone diameter from Red Hill and Milligan Canyon. Most of them are fragmentary or somewhat crushed.

Diagn osis. Species of Pernoceras with thickly discoid conch at $8 \mathrm{~mm} \mathrm{dm}(\mathrm{ww} / \mathrm{dm}=0.50-0.55)$ and thinly discoid conch at $20 \mathrm{~mm} \mathrm{dm}(\mathrm{ww} / \mathrm{dm}=0.35-0.45)$. Umbilicus funnel-shaped, moderately wide in early juveniles and very narrow between 8 and $20 \mathrm{~mm} \mathrm{dm}$ (uw/dm $=0.05-0.10)$. Septa widely spaced in juveniles and closely crowded in the adult stage; suture line with shallow, asymmetric adventive lobe. Steinkern smooth.

Description. Little can be added to the comprehensive descriptions of the species provided by Raymond (1909), Miller (1938), and House (1965). The largest available specimen MB.C. 9140.1 is, at $24 \mathrm{~mm}$ conch diameter, fully chambered and possesses 24 septa on the last volution, with a tendency towards crowding at the end. It is a discoid conch $(\mathrm{ww} / \mathrm{dm}=0.41)$ with a very narrow, funnel-shaped umbilicus. The umbilical wall stands diagonally and is separated from the flanks by a narrowly rounded margin. This is the widest point of the conch; the flanks converge towards the rounded venter (Fig. 2B). The suture line is typical for a tornoceratid ammonoid and possesses an asymmetric, rounded adventive lobe and a small, $\mathrm{V}$-shaped external lobe (Fig. 3C).
The smaller specimens MB.C.9145.1 and MB.C.9145.2 (7 mm dm) closely resemble one another (Fig. 2C, D); they possess 13 and 12 septa, and have a conch morphology that closely resembles the large specimen MB.C.9140.1. They show with a rather conspicuous subangular umbilical margin. The suture line of specimen MB.C.9145.1 has a shallow adventive lobe (Fig. 3B).

Discussion. Pernoceras crebriseptum has affinities with species of the genus Tornoceras but differs by its open umbilicus from other species of that genus. Furthermore, its characteristic umbilical shape with the pronounced umbilical margin allows a clear separation from the stratigraphically older species. In this respect, it more closely resembles representatives of derived tornoceratids such as Gundolficeras Becker, 1995.

P. dorsatum (Wedekind, 1908) is a similar species, but has a slightly wider umbilicus and more flattened flanks.

Family Prolobitidae Wedekind, 1913

\section{Raymondiceras Schindewolf, 1934}

\section{Raymondiceras simplex (Raymond, 1909)}

Figs 2F-J, 4A-D

1909 Prolobites simplex Raymond: 152, pl. 7: figs 13, 14, pl. 8: figs $1-3$.

1909 Tornoceras crebriseptum Raymond: pl. 8: fig. 8 (only).

1934 Raymondiceras simplex. - Schindewolf: 336, textfigs $2,5 \mathrm{a}, 5 \mathrm{~b}$.

1938 Raymondiceras simplex. - Miller: 173, pl. 38: figs 1-6.

Types. Specimens 470 and 471 (Carnegie Museum, Pittsburgh). 

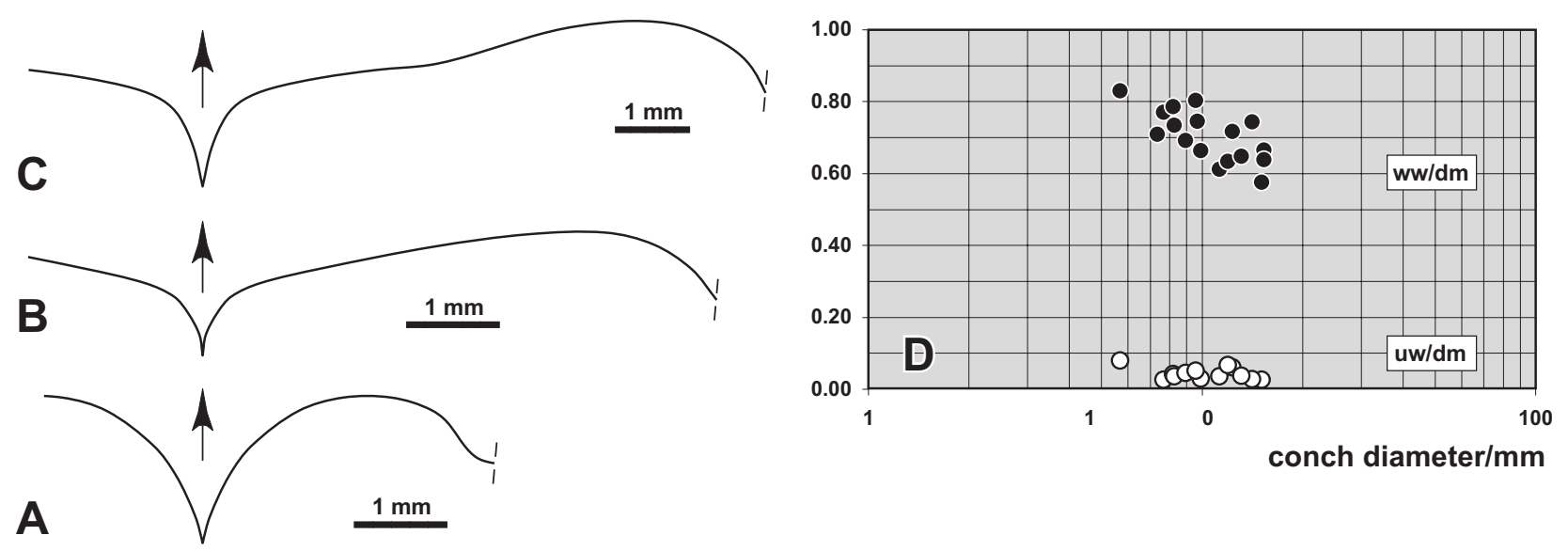

Fig. 4. Suture lines (A-C) and bivariate plots (D) of Raymondiceras simplex (Raymond, 1909) from the Three Forks Shale. A - specimen MB.C.9146.1 from Milligan Canyon (sample TF-3), at $\mathrm{dm}=5.2 \mathrm{~mm}, \mathrm{ww}=5.1 \mathrm{~mm}$, wh $=2.9 \mathrm{~mm}, \times 10 ; \mathbf{B}-$ specimen MB.C. 9134.3 from Red Hill, at $\mathrm{dm}=10.3 \mathrm{~mm}$, ww $=6.4 \mathrm{~mm}$, wh $=6.2 \mathrm{~mm}, \times 10 ; \mathbf{C}-$ specimen MB.C. 9134.1 from Red Hill, at wh $=7.6 \mathrm{~mm}, \times 8 ; \mathbf{D}-$ Ontogenetic development of the whorl width index $(\mathrm{ww} / \mathrm{dm})$ and umbilical width index (uw/dm).

Type locality and horizon. Three Forks (Montana); basal portion (red shale) of the Trident Member of the Three Forks Shale (probably Platyclymenia annulata Zone, Famennian).

Material. 48 specimens between 5 and $22 \mathrm{~mm}$ conch diameter are available from Milligan Canyon and Red Hill. Most of them are fragments of phragmocones.

Diagnosis. Species of Raymondiceras with thickly pachyconic conch at $6 \mathrm{~mm} \mathrm{dm}(\mathrm{ww} / \mathrm{dm}>0.80)$ and thinly pachyconic conch at $15 \mathrm{~mm} \mathrm{dm}(\mathrm{ww} / \mathrm{dm}=0.55-0.70)$. Umbilicus very narrow between 6 and $15 \mathrm{~mm} \mathrm{dm}(\mathrm{uw} / \mathrm{dm}=0.03-0.10)$. Septa widely spaced in juveniles and closely crowded in the adult stage; suture line always very simple without or with only barely visible adventive lobe. Ornament in the adult stage with fine spiral lines on the venter.

Description. The largest available specimen MB.C.9134.1 has a conch diameter of $22 \mathrm{~mm}$ and is laterally crushed (Fig. $2 \mathrm{H}$ ). It can be regarded as a mature conch with more or less completely preserved body chamber, indicated by extreme septal crowding in the last segment of the phragmocone. Within an interval of only $60^{\circ}$, the distances of septa are reduced from about $20^{\circ}$ to only $2.5^{\circ}$, a distance unique for all known $\mathrm{Pa}-$ laeozoic ammonoids. The course of the outer suture line is simple with a wide and low saddle on the flank and a small external lobe (Fig. 4C). The steinkern surface shows some indications of convex, periodically strengthened growth lines and about 25 spiral lines that are restricted to the outer flanks and the venter.

Several of the smaller specimens are well preserved and can are used for the description of the morphology. Specimen MB.C.9149.1 has a diameter of $12 \mathrm{~mm}$ and fully septate with 8 chambers. It is pachyconic $(\mathrm{ww} / \mathrm{dm}=0.72)$ with an almost closed umbilicus. The steinkern is smooth, and the suture line extends with a wide and low arch across the flanks (Fig. 2J). Specimen
MB.C.9134.2 (9 $\mathrm{mm} \mathrm{dm})$ has a narrower conch $(w w / d m=0.66)$ and 7 chambers (Fig. $2 F)$, and the small individual MB.C.9146.1 (5.7 mm dm) is thickly pachyconic $(\mathrm{ww} / \mathrm{dm}=0.82)$ and possesses only five septa per whorl (Fig. 2G). The suture line of this specimen has a wide saddle on the flank and a V-shaped external lobe (Fig. 4A). There is no modification during ontogeny within these specimens.

R e marks. The species was comprehensively described and discussed by Raymond (1909), Schindewolf (1934), and Miller (1938), but these authors did not solve the phylogenetic relationships of this peculiar species. Miller \& Furnish (1957) as well as Petersen (1975) treated Raymondiceras as the type of an own subfamily within the cheiloceratids. House (1962) regarded Raymondiceras simplex as a close relative to the Middle Devonian homeomorphic genus Sobolewia Wedekind, 1918. Later (House 1981), he treated it as a prolobitid ammonoid, as Raymond did, and put the two genera Sobolewia and Raymondiceras in the family Prolobitidae.

Becker (1993) placed Raymondiceras simplex, together with a number of early Famennian homeomorphs, into a subgenus of Cheiloceras Frech, 1897, and extended the taxon morphologically and stratigraphically. These cheiloceratids, which differ from typical Cheiloceras in the much higher aperture, were then summarised by Korn (in Korn \& Ziegler 2002) in the new genus Nehdenites Korn, 2002, and Raymondiceras was there restricted to forms with a low aperture and convex sutures. At the same time, Korn (2002) described the new genus and species Roinghites bottkei from the Platyclymenia annulata Zone of 
Kattensiepen in the Rhenish Mountains, being the first raymondiceratid from Central Europe. Here it was shown that there are good reasons to follow the interpretation that the taxa under consideration are secondarily simplified prolobitid ammonoids.

Suborder Clymeniina Hyatt, 1884

Family Platyclymeniidae Wedekind, 1914

\section{Platyclymenia Hyatt, 1884}

\section{Platyclymenia montana n. sp.}

Figs $5 \mathrm{~A}-\mathrm{D}, 6 \mathrm{~A}, \mathrm{~B}$

Derivation of name. After the state of Montana, where the material was collected.

Holotype. Specimen MB.C.9129.1 (coll. Titus); illustrated here in Fig. 5A.

Type locatilty and horizon. Red Hill (Montana); basal portion (red shale) of the Trident Member of the Three Forks Shale (probably Platyclymenia annulata Zone, Famennian).

Material. 19 specimens between 15 and $52 \mathrm{~mm}$ conch diameter, many of them more or less complete phragmocones from Red Hill and Milligan Canyon. Another 43 fragments are available, but their assignment to the species is not certain.

Diagnosis. Species of Platyclymenia with discoid conch $(w w / d m=0.40)$; whorl width/whorl height ratio $(w w / w h)=$ $1.00-1.25$. Whorls rather rapidly expanding $(\mathrm{WER}=2.05-$ $2.20)$. Umbilicus moderately wide (uw/dm $=0.35-0.42$ ). Ornament with 15-23 sharp, slightly concave ribs on the flanks. Growth lines with deep, semicircular ventral sinus. Septa widely spaced in juveniles and closely crowded in the adult stage; suture line with asymmetric, shallow lateral lobe and high external saddle.

Description. The larger specimens (up to $52 \mathrm{~mm}$ in conch diameter) of the species are not well preserved, unfortunately, because they are thickly encrusted by markasite aggregates or are somewhat crushed.
The smaller specimens are better preserved. Holotype MB.C.9129.1 is an incomplete specimen but displays the ontogenetic changes of the conch (Fig. 5A). There is a reduction of the whorl width/whorl height ratio from about 1.50 to 1.00 within a growth interval between 4 and $18 \mathrm{~mm}$ diameter. At the same time, the umbilical width ratio remains stable with $0.40-0.42$. The whorl expansion rate increases from 2.00 at $4 \mathrm{~mm}$ $\mathrm{dm}$ to more than 2.20 in stages larger than $12 \mathrm{~mm} \mathrm{dm}$. The suture line of the specimen has a shallow and wide lateral lobe that occupies the entire flank; it continues into a broadly rounded, raised external saddle (Fig. 6A, B).

Paratype MB.C.9145.2 (Fig. 5B) has $20 \mathrm{~mm}$ conch diameter and displays the characteristics of the intermediate stage. The conch is discoid $(\mathrm{ww} / \mathrm{dm}=0.38)$ with a moderately wide umbilicus $(\mathrm{uw} / \mathrm{dm}=0.40)$. It has $17 \mathrm{ribs}$ on the last whorl; they are strongest on the inner flank, where they almost form elongate nodes, and wedge out towards the venter. They extend in slightly forward direction with a barely visible lateral sinus across the flank. The phragmocone has 19 chambers on the last volution, but towards the aperture, there occurs a significant crowding. The suture line possesses a slightly asymmetric, shallow and wide lateral lobe and a raised external saddle.

Paratypes MB.C.9145.3 and MB.C.9145.4, both with approximately $17 \mathrm{~mm}$ conch diameter, are fully septate specimens (Fig. 5C, D). They are ornamented with 18-19 ribs, as in specimen MB.C.9145.2. The suture line of these two specimens also closely resemble that of specimen MB.C.9145.2, but there occur remarkable differences in septal spacing between specimens MB.C.9145.3 (with 22 chambers per whorl) and

Fig. 5. Clymeniid ammonoids from the Three Forks Shale of Montana, all coll. Titus. A - Platyclymenia montana n. sp., holotype MB.C.9129.1 from Red Hill, ventral and lateral views, $\times 2$; $\mathbf{B}$ - Platyclymenia montana n. sp., paratype MB.C.9145.2 from Red Hill, ventral and lateral views, $\times 2 ; \mathbf{C}-$ Platyclymenia montana n. sp., paratype MB.C.9145.3 from Red Hill, dorsal and lateral views, $\times 2$; D - Platyclymenia montana n. sp., paratype MB.C.9145.4 from Red Hill, dorsal and lateral views, $\times 2$; E - Platyclymenia cf. montana n. sp., specimen MB.C.9138.1 from Milligan Canyon, lateral and ventral views, $\times 2$; $\mathbf{F}-$ Platyclymenia sp., specimen MB.C.9142 from Milligan Canyon (sample TF-2), dorsal and lateral views, $\times 2$; G - Platyclymenia sp., specimen MB.C.9130.1 from Red Hill, lateral view, $\times 1$; H - Pleuroclymenia americana (Raymond, 1907), specimen MB.C.9131.1 from Red Hill, dorsal and lateral views, $\times 1$; I - Pleuroclymenia americana (Raymond, 1907), specimen MB.C.9131.2 from Red Hill, dorsal and lateral views, $\times 1$; J - Pleuroclymenia americana (Raymond, 1907), specimen MB.C.9131.4 from Red Hill, dorsal and lateral views, $\times 1$; $\mathbf{K}-$ Pleuroclymenia americana (Raymond, 1907), specimen MB.C.9139.1 from Milligan Canyon, dorsal and lateral views, $\times 2 ; \mathbf{L}-$ Pleuroclymenia americana (Raymond, 1907), specimen MB.C.9131.5 from Red Hill, ventral and lateral views, $\times 2$; $\mathbf{M}-$ Pleuroclymenia americana (Raymond, 1907), specimen MB.C.9131.3 from Red Hill, ventral and lateral views, $\times 1$; $\mathbf{N}-$ Pleuroclymenia americana (Raymond, 1907), specimen MB.C.9147.2 from Milligan Canyon (sample TF-3), lateral and ventral views, $\times 2$; $\mathbf{0}-$ Pleuroclymenia americana (Raymond, 1907), specimen MB.C.9147.1 from Milligan Canyon (sample TF-3), dorsal and lateral views, $\times 2$; P - Carinoclymenia sp., specimen MB.C.9135 from Red Hill, ventral and lateral views, $\times 2$. 

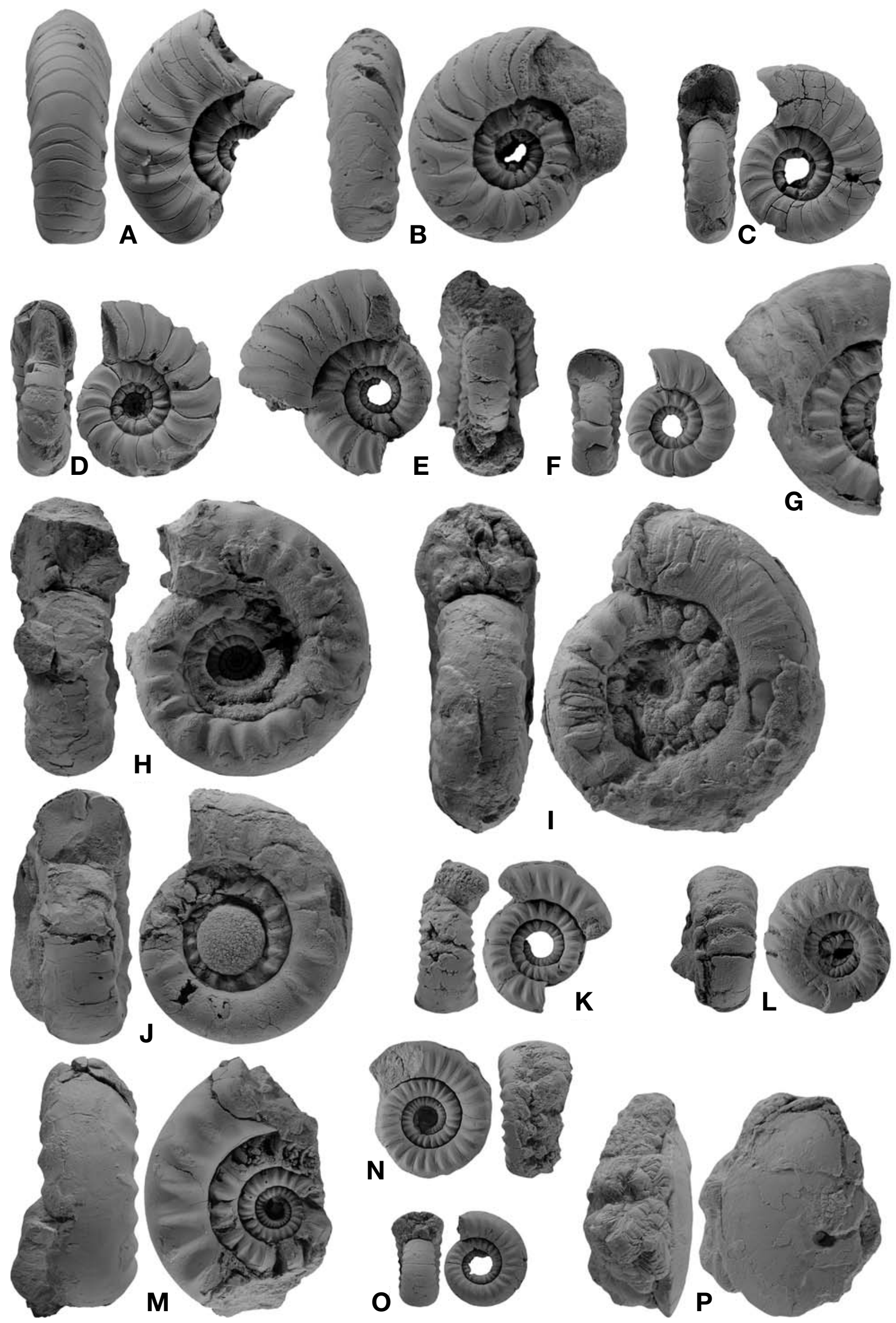

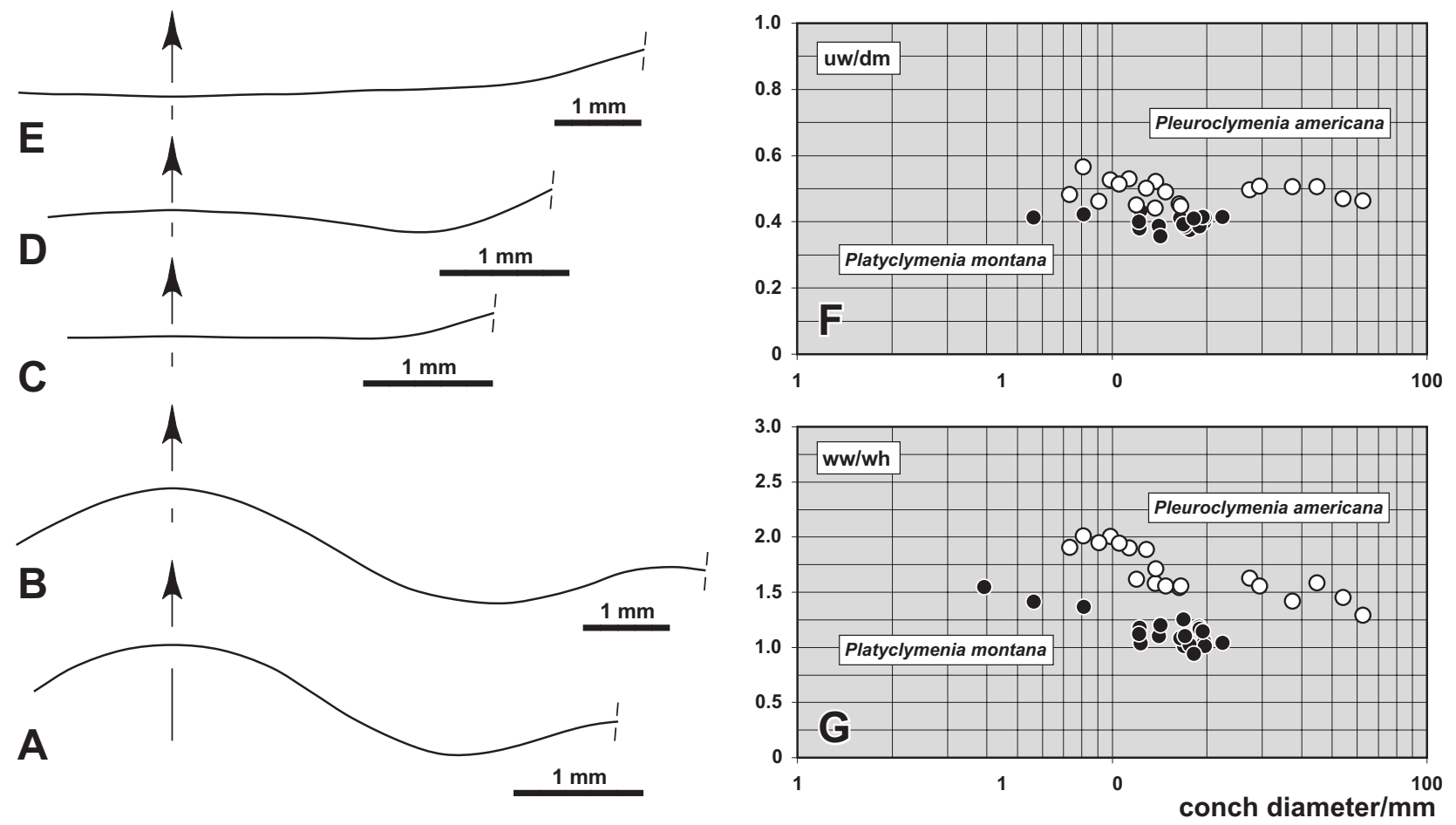

Fig. 6. Suture lines (A-E) and bivariate plots (F, G) of Platyclymenia montana n. sp. and Pleuroclymenia americana (Raymond, 1907) from the Three Forks Shale. A-Platyclymenia montana n. sp., holotype MB.C.9129.1 from Red Hill, at $\mathrm{dm}=12.8 \mathrm{~mm}, w w=4.7 \mathrm{~mm}, w h=4.4 \mathrm{~mm}, \times 15 ; \mathbf{B}-$ same specimen, at $\mathrm{dm}=12.8 \mathrm{~mm}, w \mathrm{w}=7.9 \mathrm{~mm}, w h=8.2 \mathrm{~mm}, \times 10$; C - Pleuroclymenia americana (Raymond, 1907), specimen MB.C.9147.1 from Milligan Canyon (sample TF-3), at $\mathrm{dm}=8.7 \mathrm{~mm}, \quad \mathrm{ww}=4.5 \mathrm{~mm}, \quad \mathrm{wh}=2.2 \mathrm{~mm}, \quad \times 15 ; \quad$ D - Pleuroclymenia americana (Raymond, 1907), same specimen MB.C.9139.1 from Milligan Canyon, at $\mathrm{dm}=9.9 \mathrm{~mm}$, ww $=5.0 \mathrm{~mm}$, wh $=2.9 \mathrm{~mm}, \times 15 ; \mathbf{E}-$ Pleuroclymenia americana (Raymond, 1907), specimen MB.C.9131.4 from Red Hill, at ww $=12.3 \mathrm{~mm}$, wh $=6.9 \mathrm{~mm}, \times 10 ; \mathbf{F}-$ ontogenetic development of the umbilical width index (uw/dm) and differences between Platyclymenia montana $\mathrm{n}$. sp. and Pleuroclymenia americana (Raymond, 1907); G - ontogenetic development of the whorl width index (ww/wh) and differences between Platyclymenia montana n. sp. and Pleuroclymenia americana (Raymond, 1907).

specimen MB.C.9145.4 (with 14 chambers per whorl).

Specimen MB.C.9138.1 with $20 \mathrm{~mm}$ conch diameter is a specimen that possibly belongs to another species (Fig. 5E). It belongs to the more thickly discoid individuals of Platyclymenia (ww/ $\mathrm{wh}=1.35$ at $19 \mathrm{~mm} \mathrm{dm})$, and has a moderately wide umbilicus (uw/dm $=0.43$ ). It displays significant crowding of septa; the penultimate whorl with $13 \mathrm{~mm}$ conch diameter has 10 chambers, and only one quarter of the following whorl has already 10.

Septal crowding is common in many of the specimens. Holotype MB.C.9129.1, for instance, has septa that stand in distances of $15-20^{\circ}$ at $12 \mathrm{~mm}$ conch diameter. One whorl later, at about $22 \mathrm{~mm} \mathrm{dm}$, they have distances of only $5-7^{\circ}$.

Discussion. The new species belongs, with a uw/dm ratio of 0.40 , to the more narrowly umbilicate species of the genus. This character, combined with the high aperture (WER $=2.10$ 2.20), makes the species easily distinguishable from most of the other species. Species with a similarly narrow umbilicus are, from the Holy Cross Mountains of Poland, P. inflata Czarnocki, 1989 with an even narrower umbilicus (uw/ $\mathrm{dm}=0.35)$, P. limata Czarnocki, 1989 and P. laxata Czarnocki, 1989, both insufficiently described and probably with much finer ribbing. P. nodosa Gümbel, 1863 and P. arieticostata Schindewolf, 1923 from Franconia are similar in the width of the umbilicus, but have a compressed whorl cross section, in contrast to the depressed or circular in the new species. P. arieticostata has stronger ribs than P. montana, and P. nodosa possesses node-like ribs. Finally, the Moroccan P. ibnsinai Korn, 1999 resembles the new species in umbilical width and apertural height, but this has also more compressed whorls. The ww/wh ratio is $0.25-0.28$ in P. ibnsinai, but $0.38-0.42$ in P. montana at about $22 \mathrm{~mm}$ conch diameter.

Platyclymenia montana can easily be separated from the co-occurring Pleuroclymenia americana by its laterally compressed whorl section and the much higher external saddle of the suture line. 


\section{Platyclymenia sp.}

Fig. 5E-H

Material. One small complete and three larger fragmentary specimens are available from Red Hill and Milligan Canyon. They range between 12 and approximately $60 \mathrm{~mm}$ in diameter.

Description. Specimen MB.C.9130.1 (Fig. 5G) is a fragment of a specimen with about $45 \mathrm{~mm}$ diameter; it has laterally compressed whorls $(\mathrm{ww} / \mathrm{dm}=0.90)$ and a wide umbilicus (uw/ $\mathrm{dm}=0.47)$. It bears 9 ribs on the penultimate half whorl; they are restricted to the flanks and reach almost to the umbilical seam.

The small, well preserved specimen MB.C.9142 (Fig. 5F) has $12.5 \mathrm{~mm}$ diameter and the conch ratios $\mathrm{ww} / \mathrm{dm}=0.45, \mathrm{ww} / \mathrm{wh}=1.40, \mathrm{uw} / \mathrm{dm}=0.45$. It therefore does not fall in the range of the other platyclymeniid species from the Three Forks Shale. The whorl cross section is ventrally depressed, oval-shaped and widest near the umbilicus. The last volution possesses 19 sharp ribs; they extend with a shallow concave sinus across the flank and disappear suddenly ventrolaterally. The suture line has a shallow lateral lobe and a raised external saddle.

Discussion. The material is too insufficient to be attributed to a distinct species. It has some similarity with Platyclymenia annulata (Münster, 1832), conch shape and ornament.

\section{Pleuroclymenia Schindewolf, 1934}

\section{Pleuroclymenia americana (Raymond, 1907)}

Figs 5H-O, 6C-E

1907 Pleuroclymenia americana Raymond: 118, textfig. 1.

1909 Pleuroclymenia americana. - Raymond: 150, pl. 6: fig. 10-13, pl. 7: fig. 2, 3 (only).

1909 Pleuroclymenia polypleura Raymond: 151, pl. 7: figs 4-6.

1934 Platyclymenia (Pleuroclymenia) americana. - Schindewolf: 340 , textfigs 10,11 .

1934 ?Platyclymenia (Pleuroclymenia) polypleura. - Schindewolf: 344.

1938 Platyclymenia (Pleuroclymenia) americana. - Miller: 196, pl. 39: figs 1-7.

1938 Platyclymenia (Pleuroclymenia) polypleura. - Miller: 196, pl. 39: figs 11-16.

1962 Platyclymenia (Pleuroclymenia) americana. - House: pl. 47: fig. 10.

1962 Platyclymenia (Pleuroclymenia) polypleura. - House: pl. 47: fig. 7.

Types. Four syntypes are stored in the Carnegie Museum at Pittsburgh, Pennsylvania, numbered 456-559. Neither Raymond $(1907,1909)$ nor Miller (1938), in his revision, designated a lectotype, and hence the largest and most complete specimen (456, the first specimen figured by Raymond and later illustrated by House 1962) of the series is proposed here for the lectotype.
Type locality and horizon. Three Forks (Montana); basal portion (red shale) of the Trident Member of the Three Forks Shale (probably Platyclymenia annulata Zone, Famennian).

Material. 21 specimens are available from Red Hill and Milligan Canyon; they range in their sizes from a few millimetres up to $55 \mathrm{~mm}$ in diameter. Additionally, 70 fragments are available.

Diagnosis. Species of Pleuroclymenia with thickly discoid conch at $10 \mathrm{~mm} \mathrm{dm}(w w / d m=0.50-0.60)$ and thinly discoid conch at $60 \mathrm{~mm} \mathrm{dm}(\mathrm{ww} / \mathrm{dm}=0.35-0.40)$. Whorls twice as wide as high at $10 \mathrm{~mm} \mathrm{dm}(\mathrm{ww} / \mathrm{wh}=1.80-2.10)$, decreasing to $1.30-1.60$ at $25-60 \mathrm{~mm} \mathrm{dm}$. Umbilicus wide throughout ontogeny ( $\mathrm{uw} / \mathrm{dm}=0.45-0.55)$. Ornament with $18-25$ sharp, almost linear ribs on the flanks. Growth lines with deep, semicircular ventral sinus. Septa widely spaced in juveniles and closely crowded in the adult stage; suture line always very simple with very shallow lateral lobe.

Description of new material. Specimen MB.C.9131.1 (Fig. 5H) is the second-largest available specimen; it has a conch diameter of $55 \mathrm{~mm}$ and is, apart from some markasite encrustation, well preserved. It is a discoid conch (ww/ $\mathrm{dm}=0.40)$ with a wide umbilicus $(\mathrm{uw} / \mathrm{dm}=0.48)$ and ventrally depressed, wide whorls (ww/ $w h=1.45$ ). The ornament of the last four whorls can be studied, allowing the observation of changes in the shape of the ribs. On these four whorls, the rib number is almost constant, with a slight decrease from 21 to 19. On the inner whorls, however, the ribs are much sharper. The last whorl shows weakened ribs that are strongest on the inner flank and wedge out towards the venter and the umbilical wall. They extend in almost linear course across the flanks. Some remains of the shell are visible on this specimen. There are fine growth lines following the almost linear course of the ribs, and turn back to form a semicircular, rather deep ventral sinus. The inner whorls display ribs, which run concavely in a very shallow sinus across the flanks.

Specimen MB.C.9131.2 (Fig. 5I) is the largest individual with $62 \mathrm{~mm}$ diameter. Only portions of the last volution are free from secondary encrustration, and these portions show the transition from the ribbed stage into the adult nonribbed stage. At the end of the last preserved whorl, there are rough and occasionally strengthened growth lines that run with slightly backward direction across the flank and form a rather deep ventral sinus.

Specimen MB.C.9131.3 (Fig. 5M) shows the pre-adult morphology and ornament of the outer whorl (appr. $48 \mathrm{~mm} \mathrm{dm}$ ). The number of ribs decreases from 26 (appr. $9 \mathrm{~mm} \mathrm{dm}$ ) to about 20 (at $30 \mathrm{~mm} \mathrm{dm}$ ). The fourth rather large specimen MB.C.9131.4 differs in a lower number of 
ribs, being 16 on one whorl with a maximum diameter of $36 \mathrm{~mm} \mathrm{dm}$.

The small specimens MB.C.9147.1 (9 mm dm) and MB.C.9147.2 (12.8 $\mathrm{mm} \mathrm{dm})$ display the juvenile conch morphology that is characterised by strongly depressed whorls with flattened venter and with whorls that are almost twice as wide as high (Fig. 5O, N). They have a trapezoidal cross section and are widest at the transition from the flank to the venter. Both specimens have 24 ribs on the last preserved whorl; these are barely concave towards the aperture and restricted to the flanks. Both specimens show the ventral suture line, which runs almost straight without any lobes and saddles.

The suture lines of specimens MB.C.9147.1 and MB.C.9139.1 show, at 9 and $10 \mathrm{~mm}$ conch diameter, a very shallow lateral lobe. This outline with an almost linear course across the venter is also present in the larger specimen MB.C.9131.4 at approximately $25 \mathrm{~mm} \mathrm{dm}$ (Fig. 6C-E).

Discussion. Raymond (1909, p. 151) as well as Miller (1938, p. 198) separated the two species $P$. americana and P.polypleura on the base of the number of ribs, a criterion questioned by Schindewolf (1934). Miller pointed out that there are practically no differences in conch morphology between the two forms. The new material shows that a continuous range in the rib number from about 18 to 30 , with most specimens being close to 24 . Furthermore, there occurs a more or less well-developed reduction of the number of ribs during ontogeny. The second criterion, i.e., the number of phragmocone chambers per whorl, does not separate two species. Septal spacing has been shown to depend partially on environmental conditions and is highly variable in the material, and it is not possible to find a correlation of number of septa and number of ribs, as stated by Miller (1938, p. 199). As some specimens show, there are even significant differences within the whorls of a single individual.

Many other species of Pleuroclymenia, such as P. ohioensis House, Gordon \& Hlavin, 1986 are usually narrower umbilicate than P.americana. The type species P. costata (Lange, 1929) resembles the American species in its conch dimensions and ornament, but becomes much earlier unribbed in ontogeny. P. evoluta (Czarnocki, 1989) and P. cyclocostata (Czarnocki, 1989) are very similar in shape and ornament, but differ in the presence of constrictions.
Family Carinoclymeniidae Bogoslovsky, 1975

\section{Carinoclymenia Bogoslovsky, 1965}

\section{Carinoclymenia sp.}

Fig. 5P

Material. One fragmentary specimen with approximately $22 \mathrm{~mm}$ conch diameter from Red Hill.

Description. The single specimen MB.C.9135 is a flat discoid conch with a sharp venter and a very narrow umbilicus. It is a fragment of the body chamber that is almost smooth and does not show any traces of an ornament. In these characters, it closely resembles C. beuelensis (Lange, 1929), but the specimen is too poorly preserved for a distinct attribution.

\section{Septum distances of the ammonoids}

A common feature shared by all of the specimens, regardless their attribution to different ammonoid clades, is the striking variability in spacing of the septa. Septal crowding is a character that is usually connected with adultness of specimens and is often used as a criterion for terminal growth. In fact, extreme septal approximation was shown for instance by Bogoslovsky (1969) and Korn et al. (1984) for the mid-Famennian genus Prolobites Wedekind, 1913, in which reduction of septal spacing can be linked with adult modifications of the terminal aperture, i.e., the deceleration of accretion of shell material. In this case, it can be assumed that temporal production of new septa is not slowed down; it is only the spaces that became shorter.

It is difficult to tell if such conditions are present in any case of septal approximation in ammonoids. To test of such a hypothesis, extremely well-preserved material has to be examined, which shows septal crowding and also aperture modifications at corresponding diameters. It is likely, however, that septal crowding is, in most of the cases, correlated with slower accretion at the aperture. This provides a proxy for ecological conditions during the life time of the ammonoid individuals.

Septal spacing can best be documented for Platyclymenia montana $\mathrm{n}$. sp., of which the specimens MB.C.9145.3, MB.C.9145.4, and MB.C.9142 were analysed (Fig. 7). These three specimens show very different patterns in their septal distances; a common feature is just the general 

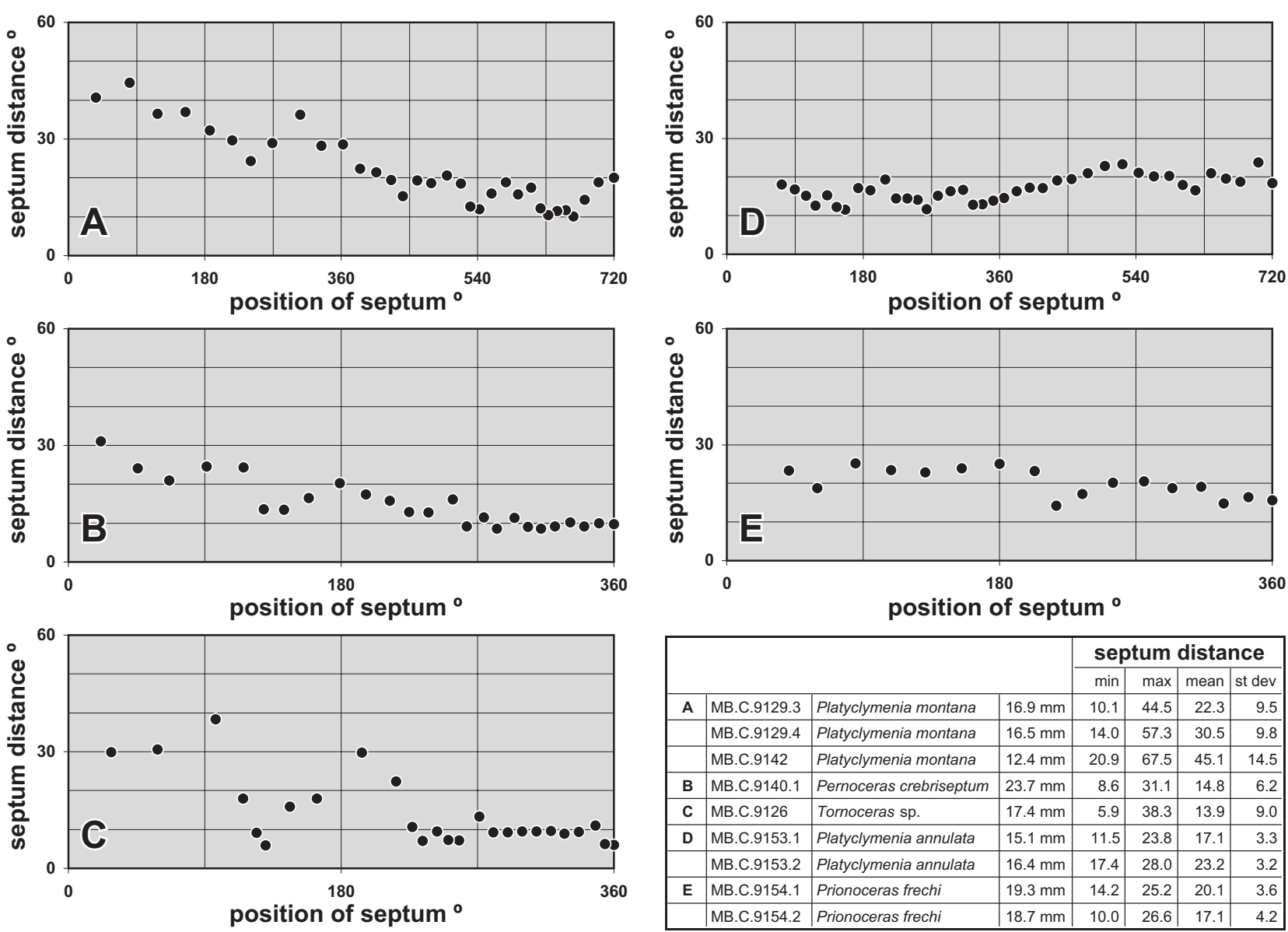

\begin{tabular}{|c|c|c|c|c|c|c|c|}
\hline & & & & \multicolumn{4}{|c|}{ septum distance } \\
\hline & & & & $\min$ & $\max$ & mean & st dev \\
\hline \multirow[t]{3}{*}{ A } & MB.C. 9129.3 & Platyclymenia montana & $16.9 \mathrm{~mm}$ & 10.1 & 44.5 & 22.3 & 9.5 \\
\hline & MB.C.9129.4 & Platyclymenia montana & $16.5 \mathrm{~mm}$ & 14.0 & 57.3 & 30.5 & 9.8 \\
\hline & MB.C.9142 & Platyclymenia montana & $12.4 \mathrm{~mm}$ & 20.9 & 67.5 & 45.1 & 14.5 \\
\hline B & MB.C. 9140.1 & Pernoceras crebriseptum & $23.7 \mathrm{~mm}$ & 8.6 & 31.1 & 14.8 & 6.2 \\
\hline C & MB.C.9126 & Tornoceras sp. & $17.4 \mathrm{~mm}$ & 5.9 & 38.3 & 13.9 & 9.0 \\
\hline \multirow[t]{2}{*}{ D } & MB.C.9153.1 & Platyclymenia annulata & $15.1 \mathrm{~mm}$ & 11.5 & 23.8 & 17.1 & 3.3 \\
\hline & MB.C.9153.2 & Platyclymenia annulata & $16.4 \mathrm{~mm}$ & 17.4 & 28.0 & 23.2 & 3.2 \\
\hline \multirow[t]{2}{*}{$E$} & MB.C. 9154.1 & Prionoceras frechi & $19.3 \mathrm{~mm}$ & 14.2 & 25.2 & 20.1 & 3.6 \\
\hline & |MB.C.9154.2 & Prionoceras frechi & $18.7 \mathrm{~mm}$ & 10.0 & 26.6 & 17.1 & 4.2 \\
\hline
\end{tabular}

Fig. 7. Septum distances of ammonoids from the Three Forks Shale of Montana and time equivalents from the Platyclymenia annulata Zone of Madène el Mrakib (Anti-Atlas, Morocco). A - Platyclymenia montana n. sp., paratype MB.C.9145.3 from Red Hill; B - Pernoceras crebriseptum (Raymond, 1909), specimen MB.C.9140.1 from Milligan Canyon; C - Tornoceras sp., specimen MB.C.9126 from Red Hill; D - Platyclymenia annulata (Münster, 1832), specimen MB.C.9153.1 from Madène el Mrakib; E - Prionoceras frechi (Wedekind, 1913), specimen MB.C.9154.1 from Madène el Mrakib.

ontogenetic decrease of spaces between the septa. This decrease can be largely continuous as in specimen MB.C.9145.3 or strikingly irregular as in specimen MB.C.9145.4. In the latter specimen, there occur dramatic fluctuations with discontinuously appearing phases of extreme septal crowding.

Reduction of septal spacing during ontogeny can also be seen in the other species within the assemblage. In all the species, septa are arranged in distances of $10^{\circ}$ or even less in the adult stage (Fig. 7B, C). Such a close spacing is very unusual for late Devonian ammonoids.

A comparison with time-equivalent material from other localities demonstrates that the specimens from the Three Forks differ at least markedly from material from Madène el Mrakib (Ma'der, Morocco). Specimens of Platyclymenia annulata (Münster, 1832) from that locality may show some irregularities in septal spacing (Fig. 7D), but to a much lower degree than seen in the platyclymeniids from Montana. Pernoceras and Raymondiceras are not known from this North African assemblage, but Prionoceras frechi (Wedekind, 1913), for instance, does not show septal crowding (Fig. 7E). Variation of septal spacing during one or two volutions can be expressed in the minimum and maximum, as well as the standard deviation. This value ranges between 3.2 and 4.2 in the analysed Moroccan specimens of Platyclymenia annulata and Prionoceras frechi, but amounts between 6.2 and 14.5 in the specimens of different species from the Three Forks.

\section{Conclusions}

The ammonoid fauna of the Three Forks Shale of Montana is one of the most diverse Famennian assemblages in the New World and deserves attention for its stratigraphic position and its genus composition in a palaeobiogeographic context. The co-occurrence of the genera Platycly- 
menia, Pleuroclymenia, and Carinoclymenia is a good evidence for a position within the middle Famennian Platyclymenia annulata Zone, from which assemblages with morphologically similar species are particularly well known from Central and Eastern Europe and North Africa. On the other hand, the fauna from the Three Forks also contains the genera Tornoceras and Pernoceras, which are only known from stratigraphically older deposits of the Old World, i.e., the early Famennian. Raymondiceras is possibly an endemic genus in North America, but close relatives are already known from time-equivalent horizons of Australia, the South Urals, and the Rhenish Mountains. This pattern in the distribution of the discussed genera speaks for a connection of the shelf regions, and differences of the compositions may largely be caused by ecological reasons.

The Three Forks assemblage appears to be unique in the fact that all ammonoid taxa display significant irregularities in the spacing of the septa, regardless their systematic position. Septal crowding does not only occur as a phenomenon of terminal growth, where it is particularly well known, but also in intermediate stages, followed by phases with wider septal interspaces. Such patterns speak for instable conditions during the lifetime of the ammonoids.

\section{Acknowledgements}

We are grateful to Wolfgang Gerber (Tübingen) for the photography of the specimens, and we acknowledge the reviews by Susan Klofak (New York), Christian Klug (Zürich), and $\mathrm{Al} \mathrm{McGowan} \mathrm{(London).}$

\section{References}

Arthaber, G. von 1911. Die Trias von Albanien. - Beiträge zur Paläontologie und Geologie Österreich-Ungarns und des Orients 24: 169-277.

Becker, R. T. 1993. Stratigraphische Gliederung und Ammonoideen-Faunen im Nehdenium (Oberdevon II) von Europa und Nord-Afrika. - Courier Forschungsinstitut Senckenberg 155: 1-405.

- 1995. Taxonomy and Evolution of Late Famennian Tornocerataceae (Ammonoidea). - Berliner geowissenschaftliche Abhandlungen E16 (Gundolf-Ernst-Festschrift): 607-643.

Bogoslovsky, B. I. 1960. Novye predstavateli nekotorykh maloizvest'nikh rodov devonskikh ammonoidey iz famenskikh otlozheniy Urala. - Paleontologicheskiy Zhurnal 1960 (4): 69-73.

- 1965. Carinoclymenia - noviy rod semeystva Rectoclymeniidae. - Paleontologicheskiy Zhurnal 1965 (4): 88-91.

- 1969. Devonskie ammonoidei. I. Agoniatity. - Trudy Paleontologicheskogo Instituta Akademiya Nauk SSSR 124: $1-341$.

- 1971. Devonskie ammonoidei. II. Goniatity. - Trudy Paleontologicheskogo Instituta Akademiya Nauk SSSR 127: $1-228$.
1975. Novoye semeystvo klimeniy. - Paleontologicheskiy Zhurnal 1975 (3): 35-41.

Czarnocki, J. 1989. Klimenie Gór Swietokrzyskich. - Prace Panstwowego Instytutu Geologicznego 127: 1-91.

Frech, F. 1897-1902. Lethaea geognostica oder Beschreibung und Abbildung der für die Gebirgs-Formationen bezeichnendsten Versteinerungen. I. Theil. Lethaea palaeozoica. 2. Band. IV. - 257-452, Stuttgart (Schweizerbart).

Gümbel, C. W. 1863. Über Clymenien in den Übergangsgebilden des Fichtelgebirges. - Palaeontographica 11: 85-165

House, M. R. 1962. Observations on the ammonoid succesion of the North American Devonian. - Journal of Paleontology 36: 247-284.

- 1965. A study in the Tornoceratidae: the succession of Tornoceras and related genera in the North American Devonian. - Philosophical Transactions of the Royal Society of London, Ser. B, Biological Science, No. 763, Vol. 250: $79-130$.

- 1981. On the Origin, Classification and Evolution of the early Ammonoidea. - In House, M. R. \& Senior, J. R. (eds). The Ammonoidea, Systematic Association Special Volume, 18: 3-36; London (Academic Press).

House, M. R., Gordon, M. Jr. \& Hlavin, W. J. (1986): Late Devonian ammonoids from Ohio and adjacent states. Journal of Paleontology 60: 126-144.

Hyatt, A. 1883-1884. Genera of fossil cephalopods. - Proceedings of the Boston Society of Natural History 22: 253-338. (253-272 publ. 1883, 273-338 publ. 1884)

Korn, D. 1999. Famennian Ammonoid Stratigraphy of the Ma'der and Tafilalt (Eastern Anti-Atlas, Morocco). Abhandlungen der Geologischen Bundesanstalt 54, North Gondwana: Mid-Paleozoic Terranes, Stratigraphy and Biota (eds R. Feist, J. A. Talent \& A. Daurer): 147-179.

- 2002. Die Ammonoideen-Fauna der Platyclymenia annulata-Zone vom Kattensiepen (Oberdevon, Rheinisches Schiefergebirge). - In Weddige, K. \& Ziegler, W. (eds). Advances in Conodont, Devonian and Carboniferous Research. Senckenbergiana lethaea 82 (2): 557-608.

Korn, D., Price, J. D. \& Ademmer, F. 1984. Prolobites aktubensis Bogoslovskiy - eine devonische Goniatiten-Art (Ammonoidea) mit irregulärem Mundrand. - Neues Jahrbuch für Geolologie und Paläontologie, Monatshefte 1984 (2): 66-76.

Korn, D. \& Ziegler, W. 2002. The ammonoid and conodont zonation at Enkenberg (Famennian, Late Devonian; Rhenish Mountains). - In Weddige, K. \& Ziegler, W. (eds). Advances in Conodont, Devonian and Carboniferous Research. Senckenbergiana lethaea 82 (2): 453-462.

Lange, W. 1929. Zur Kenntnis des Oberdevons am Enkeberg und bei Balve (Sauerland). - Abhandlungen der PreuBischen Geologischen Landestanstalt, Neue Folge 119: $1-132$.

Miller, A. K. 1938. Devonian ammonoids of America. - Special Papers of the Geological Society of America 14: $1-262$.

Miller, A. K., Furnish, W. M. \& Schindewolf, O. H. 1957. Paleozoic Ammonoidea. In Raymond C. Moore (ed.). Treatise on Invertebrate Paleontology, Part L, Mollusca 4, Cephalopoda, Ammonoidea. - L11-L79.

Münster, G. Graf zu 1832. Ueber die Planuliten und Goniatiten im Uebergangs-Kalk des Fichtelgebirges. - 1-38; Bayreuth (Birner).

Peale, A. C., 1893, The Paleozoic section in the vicinity of Three Forks, Montana, with petrographic notes by G. P. Merrill. - U.S. Geological Survey Bulletin 110, 1-56.

Petersen, M. S. 1975. Upper Devonian (Famennian) Ammonoids from the Canning Basin, Western Australia. - Journal of Paleontology, Memoir 8: 1-55.

Raymond, P. E. 1907. On the Occurence, in the Rocky Mountains, of an Upper Devonian Fauna with Clymenia. - American Journal of Science, Ser. 4, 23: 116-122. 
- 1909. The Fauna of the Upper Devonian in Montana. Part 1. - The Fossils of the Red Shales. - Annales of the Carnegie Museum 5 (1908-1909): 141-158.

- 1912. The Clymenia fauna in the American Devonian. Proceedings of the $7^{\text {th }}$ International Zoological Congress: 741-744.

Sandberg, C. A. 1965, Nomenclature and correlation of lithologic subdivisions of the Jefferson and Three Forks Formations of southern Montana and northern Wyoming, in Contributions to stratigraphy. - U.S. Geological Survey Bulletin 1194-N, N1-N18.

Schindewolf, O. H. 1922. Einige Randbemerkungen zu E. Perna's Abhandlung "Die Ammoneen des oberen Neodevon vom Ostabhang des Südurals". - Senckenbergiana 4: 185-196.

- 1923. Beiträge zur Kenntnis des Paläozoikums in Oberfranken, Ostthüringen und dem Sächsischen Vogtlande. I. Stratigraphie und Ammoneenfauna des Oberdevons von Hof a. S. - Neues Jahrbuch für Mineralogie, Geologie und Paläontologie, Beilage-Band 49: 250-357, 393-509

- 1933. Vergleichende Morphologie und Phylogenie der Anfangskammern tetrabranchiater Cephalopoden. Eine Stu- die über Herkunft, Stammesentwicklung und System der niederen Ammoneen. - Abhandlungen der Preußischen Geologischen Landesanstalt, Neue Folge 148: 1-115.

- 1934. Über eine oberdevonische Ammoneen-Fauna aus den Rocky Mountains. - Neues Jahrbuch für Mineralogie, Geologie und Paläontologie, Beilage-Band (B) 72: 331-350.

Wedekind, R. 1908. Die Cephalopodenfauna des höheren Oberdevon am Enkeberge. - Neues Jahrbuch für Mineralogie, Geologie und Paläontologie, Beilage-Band 26: 565-633.

- 1913. Beiträge zur Kenntnis des Oberdevons am Nordrande des Rheinischen Gebirges. 2. Zur Kenntnis der Prolobitiden. - Neues Jahrbuch für Mineralogie, Geologie und Paläontologie 1913: 78-95.

- 1914. Monographie der Clymenien des Rheinischen Gebirges. - Abhandlungen der Königlichen Gesellschaft der Wissenschaften zu Göttingen, Mathematisch-Physikalische Klasse, Neue Folge 10 (1): 1-73.

- 1918. Die Genera der Palaeoammonoidea Goniatiten). Mit Ausschluß der Mimoceratidae, Glyphioceratidae und Prolecanitidae. - Paläontographica 62: 85-184.

\section{Appendix}

Conch dimensions and ratios of ammonoids from the Three Forks Shale (dm, conch diameter; ww, whorl width; wh, whorl height; uw, umbilical width; ah, apertural heigh; WER, whorl expansion rate; IZR, imprint zone rate).

\begin{tabular}{|c|c|c|c|c|c|c|c|c|c|c|}
\hline & $\mathrm{dm}$ & WW & wh & uw & $\mathrm{ah}$ & $\mathrm{ww} / \mathrm{dm}$ & ww/wh & $\mathrm{uw} / \mathrm{dm}$ & WER & IZR \\
\hline \multicolumn{11}{|l|}{ Tornoceras sp. } \\
\hline \multirow[t]{2}{*}{ MB.C.9126 } & 17.4 & 6.6 & 10.0 & 0.0 & 5.4 & 0.38 & 0.66 & 0.00 & 2.09 & 0.47 \\
\hline & 12.3 & 5.5 & 6.9 & 0.0 & - & 0.45 & 0.80 & 0.00 & - & - \\
\hline \multicolumn{11}{|c|}{ Pernoceras crebriseptum (Raymond, 1909) } \\
\hline MB.C.9140.1 & 23.8 & 9.6 & 12.6 & 1.9 & 7.2 & 0.41 & 0.76 & 0.08 & 2.06 & 0.43 \\
\hline MB.C.9145.3 & 16.1 & 7.4 & 9.9 & 0.9 & - & 0.46 & 0.75 & 0.06 & - & - \\
\hline MB.C.9133.1 & 13.6 & 7.0 & 7.2 & 0.7 & - & 0.51 & 0.97 & 0.05 & - & - \\
\hline MB.C.9136.3 & 10.3 & 5.4 & 5.9 & 0.5 & - & 0.53 & 0.92 & 0.05 & - & - \\
\hline MB.C.9136.1 & 7.7 & 4.2 & 4.2 & 0.7 & - & 0.54 & 1.00 & 0.09 & - & - \\
\hline MB.C.9136.2 & 7.3 & 3.9 & 3.9 & 0.6 & - & 0.52 & 0.98 & 0.07 & - & - \\
\hline MB.C.9145.2 & 6.7 & 3.4 & 3.3 & 1.1 & - & 0.51 & 1.04 & 0.17 & - & - \\
\hline \multicolumn{11}{|c|}{ Raymondiceras simplex (Raymond, 1909) } \\
\hline MB.C.9146.4 & 15.3 & 9.8 & 7.9 & - & - & 0.64 & 1.24 & - & - & - \\
\hline MB.C.9134.4 & 15.1 & 8.7 & 7.8 & 0.4 & 4.1 & 0.58 & 1.12 & 0.03 & 1.89 & 0.47 \\
\hline MB.C.9146.5 & 13.1 & 8.5 & 7.4 & 0.5 & - & 0.65 & 1.15 & 0.04 & - & - \\
\hline MB.C.9149.1 & 12.3 & 8.8 & 6.6 & 0.8 & 3.0 & 0.72 & 1.33 & 0.06 & 1.74 & 0.55 \\
\hline MB.C.9140.3 & 11.9 & 7.6 & 6.8 & 0.8 & - & 0.63 & 1.12 & 0.07 & - & - \\
\hline MB.C.9134.3 & 11.3 & 6.9 & 5.6 & 0.4 & 2.9 & 0.61 & 1.23 & 0.04 & 1.80 & 0.49 \\
\hline MB.C.9134.2 & 9.9 & 6.6 & 5.4 & 0.3 & 2.7 & 0.66 & 1.22 & 0.03 & 1.91 & 0.49 \\
\hline MB.C.9146.2 & 9.6 & 7.7 & 5.4 & 0.5 & - & 0.80 & 1.44 & 0.05 & - & - \\
\hline MB.C.9134.7 & 8.2 & 6.1 & 4.9 & 0.3 & - & 0.74 & 1.24 & 0.04 & - & - \\
\hline MB.C.9146.1 & 5.7 & 4.7 & - & 0.5 & - & 0.83 & - & 0.08 & - & - \\
\hline
\end{tabular}

Platyclymenia montana n. sp.

$\begin{array}{lrrr}\text { MB.C.9129.12 } & 22.4 & 8.8 & 8 . \\ \text { MB.C.9129.13 } & 19.7 & 7.5 & 7.4 \\ \text { MB.C.9129.2 } & 19.6 & 7.4 & 7.0 \\ \text { MB.C.9141.2 } & 19.4 & 7.6 & 6.7 \\ \text { MB.C.9129.11 } & 18.9 & 7.5 & 6.3 \\ \text { MB.C.9129.8 } & 17.6 & 6.6 & 6.4 \\ \text { MB.C.9129.9 } & 17.0 & 5.9 & 5.3 \\ \text { MB.C.9129.3 } & 16.9 & 6.2 & 6.1 \\ \text { MB.C. } 9129.4 & 16.5 & 5.9 & 5.5 \\ \text { MB.C.9138.2 } & 16.8 & 7.2 & 5.7 \\ \text { MB.C. } 9138.4 & 14.1 & 5.9 & 5.3 \\ \text { MB.C. } 9129.1 & 18.1 & 6.8 & 7.2 \\ & 12.2 & 5.0 & 4.5 \\ & 8.1 & 3.8 & 2.8 \\ & 5.6 & 2.9 & 2.1 \\ & 3.9 & 2.2 & 1.4\end{array}$

8.4
7.4
7.0
6.7
6.3
6.4
5.3
6.1
5.5
5.7
5.3
7.2
4.5
2.8
2.1
1.4

$\begin{array}{lll}9.3 & 7.2 & 0.39 \\ 8.1 & - & 0.38 \\ 7.9 & - & 0.38 \\ 8.1 & - & 0.39 \\ 7.7 & 5.4 & 0.40 \\ 6.6 & - & 0.37 \\ 6.6 & - & 0.34 \\ 6.6 & 5.4 & 0.37 \\ 6.8 & 5.0 & 0.36 \\ 6.6 & - & 0.43 \\ 5.5 & - & 0.42 \\ 7.4 & 6.0 & 0.37 \\ 4.9 & 4.1 & 0.41 \\ 3.4 & 2.5 & 0.46 \\ 2.3 & 1.7 & 0.52 \\ - & 1.1 & 0.56\end{array}$

1.04
1.01
1.05
1.14
1.19
1.02
1.10
1.01
1.08
1.26
1.10
0.94
1.12
1.37
1.42
1.55

0.42
0.41
0.40
0.42
0.41
0.38
0.39
0.39
0.41
0.39
0.39
0.41
0.40
0.42
0.41

2.17

0.15

0.41

0.40

0.42

0.41

0.38

0.39

0.39

0.41

0.39
0.39

0.41

0.40

0.42
0.41

-

-

$\overline{1} .98 \quad \overline{0} .14$

- $\quad-$

$2.14 \quad \overline{0} .13$

$2.07 \quad 0.08$

- $\quad-$

$2.21 \quad 0.18$

$\begin{array}{ll}2.26 & 0.09\end{array}$

$2.08 \quad 0.10$

$2.06 \quad 0.17$

$\begin{array}{lll}-\quad & 1.97 & 0.20\end{array}$




\begin{tabular}{|c|c|c|c|c|c|c|c|c|c|c|}
\hline & $\mathrm{dm}$ & ww & wh & uw & $\mathrm{ah}$ & ww/dm & ww/wh & $\mathrm{uw} / \mathrm{dm}$ & WER & IZW \\
\hline \multicolumn{11}{|c|}{ Pleuroclymenia americana (Raymond, 1907) } \\
\hline MB.C.9131.2 & 62.5 & 22.9 & 17.7 & 29.0 & - & 0.37 & 1.29 & 0.46 & - & - \\
\hline MB.C.9131.1 & 54.1 & 21.8 & 15.1 & 25.5 & - & 0.40 & 1.45 & 0.47 & - & - \\
\hline MB.C.9131.4 & 37.4 & 14.7 & 10.3 & 18.9 & 9.3 & 0.39 & 1.42 & 0.51 & 1.76 & 0.11 \\
\hline MB.C.9131.3 & 27.4 & 13.0 & 8.0 & 13.6 & - & 0.47 & 1.63 & 0.50 & - & - \\
\hline MB.C.9147.3 & 16.5 & 8.6 & 5.5 & 7.4 & - & 0.52 & 1.56 & 0.45 & - & - \\
\hline MB.C.9143.2 & 16.3 & 7.2 & 4.6 & 7.4 & - & 0.44 & 1.54 & 0.45 & - & - \\
\hline MB.C.9143.5 & 14.8 & 6.6 & 4.3 & 7.3 & - & 0.45 & 1.56 & 0.49 & - & - \\
\hline MB.C.9131.8 & 13.8 & 7.2 & 4.2 & 7.2 & - & 0.52 & 1.71 & 0.52 & - & - \\
\hline MB.C.9131.5 & 13.7 & 6.7 & 4.3 & 6.1 & - & 0.49 & 1.58 & 0.44 & - & - \\
\hline MB.C.9147.2 & 12.8 & 6.8 & 3.6 & 6.4 & 3.2 & 0.53 & 1.89 & 0.50 & 1.77 & 0.12 \\
\hline MB.C.9143.1 & 11.3 & 6.6 & 3.4 & 6.0 & - & 0.58 & 1.90 & 0.53 & - & - \\
\hline MB.C.9139.1 & 9.9 & 5.0 & 2.5 & 5.2 & - & 0.51 & 2.01 & 0.53 & - & - \\
\hline МB.C.9139.2 & 8.1 & 4.7 & 2.3 & 4.6 & - & 0.57 & 2.01 & 0.57 & - & - \\
\hline MB.C.9147.1 & 9.1 & 4.6 & 2.4 & 4.2 & 2.1 & 0.50 & 1.95 & 0.46 & 1.67 & 0.13 \\
\hline
\end{tabular}

